\title{
Serum CA 19-9 Elevated
}

National Cancer Institute

\section{Source}

National Cancer Institute. Serum CA 19-9 Elevated. NCI Thesaurus. Code C162047.

The amount of cancer antigen 19-9 present in a serum sample is elevated. 